Journal of English Language Teaching

UNNES

\title{
Implementing a mobile application Quizlet to help Senior High School students learn vocabulary
}

\author{
Alesandro Woisela Prayogi ${ }^{1}$, Mega Wulandari ${ }^{\bowtie 2}$ \\ ${ }^{1,2}$ Sanata Dharma University, Indonesia
}

\section{Article Info \\ Article History: \\ Received in 23 \\ November 2020 \\ Approved in 21 March \\ 2021 \\ Published in 31 March 2021}

\section{Keywords:}

Quizlet; mobile-

assisted language

learning; perceived

usefulness; perceived

ease of use; vocabulary

\begin{abstract}
This study analyzed how Quizlet, a digital vocabulary learning platform, was implemented in helping students learn vocabulary and how students perceive the application. There were 13 high school students of a private school in Yogyakarta who took part in this study. The vocabulary studied were taken from the students' course book which was on the level B2 of CEFR. This research employed CAR (Classroom Action Research) as its methodology. The findings of this research suggested that the students were engaged when using Quizlet during the class activity. The mean score of Perceived Usefulness is very high $(\mathrm{M}=4.03, \mathrm{SD}=0.86)$ and Perceived Ease of Use is also very high $(\mathrm{M}=4.38, \mathrm{SD}=0.75)$. This indicated that students had favorable views towards the application. The data acquired from the interview also indicated that Quizlet was a practical and easy-to-use learning platform. The application was a one-stop vocabulary learning platform. Moreover, it utilized cutting-edge technology in learning and the application was practical and easy to use. Based on the results mentioned, the researchers strongly recommend that teachers start using Quizlet to help their students learn vocabulary.
\end{abstract}

(C) 2021 Universitas Negeri Semarang

${ }^{\square}$ Correspondent Address:

B3 Building FBS Unnes

p-ISSN 2252-6706 | e-ISSN 2721-4532

Sekaran, Gunungpati, Semarang, 50229

E-mail:mega@usd.ac.id 


\section{INTRODUCTION}

Technology has been undergoing rapid advancement these past years. The internet connection can now be accessed from myriads devices. These days, students are able to get an internet connection through their mobile devices anytime and anywhere and also able to access anything they desire. Students could easily download any application they want, including learning applications, into their devices. Students' addiction toward mobile devices might be a "blessing in disguise" for themselves and for teachers. While it is dangerous for students to be too absorbed in their own world with their mobile devices, teachers may as well take the advantage of them by implementing different tools or technique in teaching using mobile devices in classroom activities.

This research will use Quizlet as the learning medium for the students in learning English. Quizlet is a popular online learning tool which can be accessed through both computer and mobile device. It can be used to study any subject, but its main feature is language learning (Kalecky, 2016). In Quizlet, students are able to do self-study to acquire their language mastery. Moreover, teachers can also make classes, invite their students, create study sets, and track their progress. Most importantly, it can be accessed freely by everyone.

In terms of learning foreign language, vocabulary is one of the most significant aspects in mastering a language that is learnt in almost all levels of education, from elementary schools, or even kindergarten, to college. Moeller et al. (2009) states that vocabulary is the main key to teaching and learning a second language in order to understand all forms of oral and written communication. This shows that learning vocabulary is essential for students in order to be able to reach the goals of learning a language. However, the way of teaching and learning vocabulary has not been improved much. Students are still learning vocabulary through books and dictionaries while technology has provided them with a more authentic, eco-friendly, and interactive method. Moreover, Barr (2016) states most vocabulary learning in todays' practices only used as an incidental learning and receives a little attention, which means that vocabulary is learnt by doing other activity such as reading. Sometimes vocabulary does not even receive any attention during the learning activity. Paribakht \& Wesche (1997) states that students only gain shallow knowledge toward the words they encounter during a reading activity. Thus, a change is required in the way teachers teach and students learn vocabulary. Based on the displayed problems, the researchers made some efforts by implementing Quizlet in classroom activities and finding out students' perception towards the application and the practice.

\section{Literature Review}

This literature review discusses related theories being used in this study and some previous studies with similar focus. The theory of vocabulary is discussed first. The next discussion includes MALL (Mobile Assisted Language Learning), TAM (Technology Acceptance Model), and Quizlet.

\section{Vocabulary}

Vocabulary is very critical in one's language mastery for without a sufficient amount of vocabulary mastery, one cannot meet the goal of learning a language. Wilkins (as cited in Thornbury, 2002) states that "without grammar very little can be conveyed, without vocabulary nothing can be conveyed". Taylor (1990), explains that vocabulary has a special importance in language learning since it is the part which will not be slowed down by age. Hence, it will be beneficial for a language learner to give more attention to vocabulary mastery when learning a language.

Nation (1990) explains four approaches of vocabulary learning from indirect to direct approaches. Direct vocabulary learning pays more attention to the vocabulary itself. Some examples of direct vocabulary learning is word guessing, learning from word lists, and vocabulary games. Indirect vocabulary learning focuses on other features. For example, when a learner is focused on his/ her reading skill, then the process of learning new vocabularies will automatically happen as he/ she reads a passage. The first approach is the most indirect approach which happens when a teacher uses simplified material. New vocabularies are given gradually to students so as not to confuse students with too many new items in the lesson. The second approach deals with unintentional vocabulary learning. Any new vocabularies will be dealt with as they unintentionally appear in the process of learning. Teachers will give the attention to the new word and learners will learn the new word moments after they encounter it. Teachers also need to explain the underlying concepts of the word such as the regular features of the spelling and the grammar rather than just explain the definition of the word. The third approach is about learning vocabulary in association with another language 
activity such as reading or speaking. The last approach, and the most direct one, deals only with vocabulary. No another language activity involved in this last approach. Learners focus and spend more time on learning vocabulary. The example is when learners learn to guess the meaning or definition of a word or when they study words' definition from dictionary.

\section{MALL (Mobile Assisted Language Learning)}

Mobile Assisted Language Learning is a subset of M-learning. Mobile Learning (m-learning) is defined as the use of handheld devices such as mobile phones, PDAs, and smartphones as a means for learners to learn through its mobility, flexibility, and interactivity (Bukharaev \& Altaher, 2017). MALL is used specifically for language learning activity that is assisted through handheld devices. Kukulska-Hulme \& Shield (2008) explain that MALL is the use of mobile technology in language learning where the mobile technology offers various advantages. Mobile technology has influenced cultural practices and provide new contexts in learning (Pachler et al., 2010). It provides many advantages such as flexible, small-sized, and user-friendly, researchers are trying to find techniques on how to use mobile technology to help learning activity (Huang et al., 2012).

A study conducted by $\mathrm{Lu}(2008)$ on vocabulary learning via short message service (SMS) with high school EFL students in Taiwan indicated that students had positive views toward the method. They believed that such method was convenient and interesting. Parallel with Lu's finding, Azabdaftari \& Mozaheb (2012) conducted an experimental study on university students in Iran. They implemented two strategies of vocabulary learning; traditional paper-based flashcards and mobilebased flashcards. The findings revealed that students who used mobile-based flashcards had much higher mean score than those who used traditional paper-based flashcards. Furthermore, the students found that using mobile phone in learning activity provided more flexibility and entertainment. Dizon (2016) conducted a study on the efficacy of Quizlet on 9 Japanese university students' vocabulary mastery. The ten-week study showed an improvement of the pre-test and the post-test score of the students. The results also indicated that they prefer using mobile devices than conventional method.

\section{TAM (Technology Acceptance Model)}

The theory of Technology Acceptance Model, henceforth TAM, was introduced by Davis (1989) and nowadays it is often used by researchers to foresee use and acceptance of information technology by its users (Surendran, 2012). In TAM, there are two factors that influence users to accept or reject any information technology; perceived usefulness and perceived ease of use (Davis, 1989). Davis believed that these two factors were important in determining one's acceptance or rejection toward any information technology. Perceived usefulness (PU) can be defined as user's individual perception toward the prospect that using particular information technology will improve the user's job or life performance (Davis \& Venkatesh, 2000). Perceived Ease of Use (PEOU), on the other hand, is "the degree to which a person believes that using a particular system would be free of effort" (Davis, 1989, p. 214). In other words, people will likely to use a system information if it will improve their performance and if it is practical for them to use.

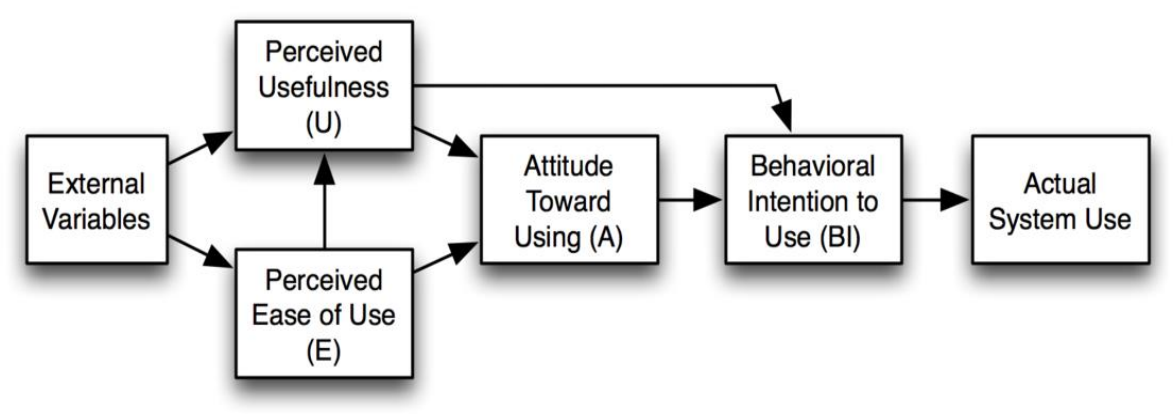

Figure 1. Technology Acceptance Model 


\section{Quizlet}

Quizlet provides attractive interface and various features to give learners a new learning experience from using the app. Quizlet can be accessed from both computer and mobile devices. Students just need to download the application and sign up to the application. They could simply sign up through their Google account. Once they have signed up, they could start searching for any type of materials that they want to learn. Furthermore, the app is free and the users could access millions of sets made in Quizlet. Quizlet will also automatically rearrange the items within the set to avoid serial learning and there are various features provided for the users to interact with (Barr, 2016).

Quizlet has some feature that is able to help students study vocabulary more easily and fun. Those features are Flashcards, Learn, Write, Spell, Match, and Test. Flashcard feature allows students to study the term and its definition by simply tapping a set of digital flashcards. Learn feature allows students to study vocabulary by answering multiple choices or written questions while Write feature requires students to type the answers of the given questions. In Match feature, students are required to match all of the terms with their definitions. Lastly, the Test feature will allow students to evaluate their knowledge about a set of vocabularies that they have learnt by answering true or false, multiple choices, and written questions.

An experimental study conducted by Baptist (2018) on 38 high school students. Among all the students, 10 of them were students with special needs. The students were divided into 2 groups, a group consisted of 20 students and other group which was consisted of 18 students. The first group were instructed to use index cards and the second one was instructed to use Quizlet. The students were given 12 words to study each week and will be given a quiz on the following meeting. After roughly 9 weeks, the treatment was switched.

The result of Baptists' study showed improvements in terms of their score in their quizzes. 16 out of 28 students (approximately 57\%) without special needs increased their score compared to the score of their quiz before Quizlet was implemented. Moreover, 7 out of 10 students (70\%) with special needs increased their score compared to the score of their quiz before Quizlet was implemented. The respond of the survey from the students also showed a positive perception toward the app. The result of the survey showed that they enjoyed the app very much and they felt that they gained a benefit from using the app.

\section{METHODS}

Classroom action research was used in this study. Reason \& Bradbury (2008)states that action research aims to combine theory and practice as a method to solve practical issues concerned with people. Wallace (2010) added that doing action research will help researchers to make decisions on what their future practice should be as it allows them to collect data from their everyday practice and analyze it.

According to Kemmis and Taggart (as cited in Khasinah, 2013), action research involves more than one cycle and consists of four steps in each cycle. Those four steps are planning, acting, observing, and reflecting. The first step is planning. In this step, the researchers focus on the problem and formulates a set plan which will be conducted to solve the problems in the research. The second step is doing the action. In the action phase, the researchers implement the activities formulated in the planning phase. The action is then observed. In this study, the aspects that were observed are the students' behavior when using Quizlet and the situation within the class when situation within the class when they are using Quizlet. The goal of the observation itself in this study is to be able to get a better understanding of how the action performed is implemented and to know the characteristics of the students. The fourth step involves the reflection that explores which problem has or has not been solved and to find out whether there is a new problem emerges when the first cycle is being conducted. After the first cycle was finished, the researchers then revised the plan based on the gathered data and the reflection. In this research, the researchers employed two cycles to correct any errors or mistakes made on the first cycle. The figure below shows the graph of action research cycle (Carr \& Kemmis, 1986). 


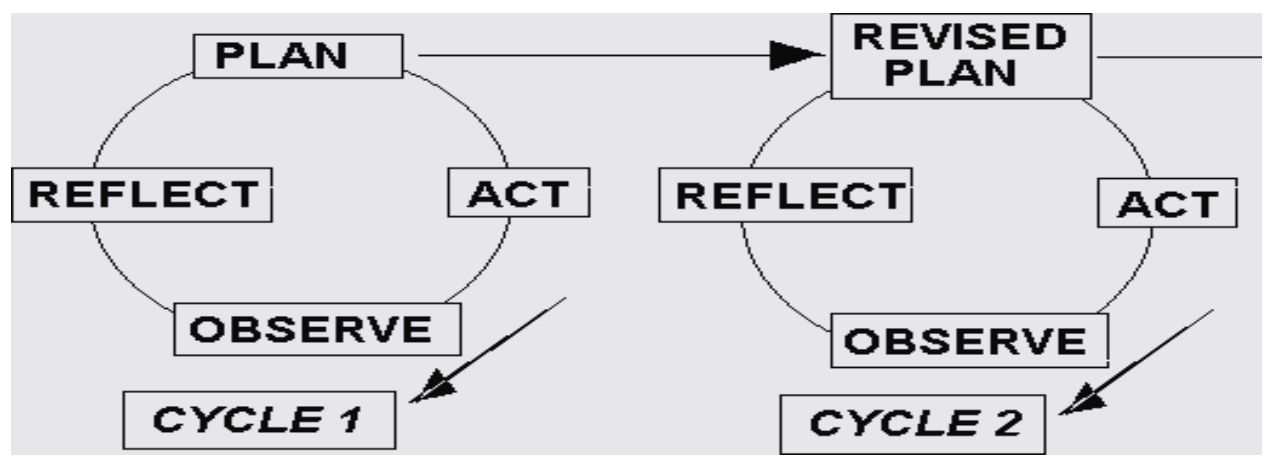

Figure 2. CAR cycle

\section{Respondents}

The participants of the study were 13 Indonesian-speaking $11^{\text {th }}$ grade students who enrolled at a private senior high school in Yogyakarta. The research was conducted in the second semester of the 2018/2019 academic year in February-June 2019. None of the students had studied abroad in an English-speaking country. Based on CEFR framework, their English level of proficiency is A2-B1.

\section{Instruments}

There were three instruments employed in this research, namely class observation, questionnaire, and interview. The observation was conducted during the implementation of Quizlet in the classroom. Observation is a technique to collect data by looking carefully at the action being performed (Ridwan, 2004). This study also used questionnaire to obtain the data from the participants about their attitudes toward Quizlet. The questionnaire was developed based on the theory of Technology Acceptance Model: perceived usefulness \& perceived ease of use (Davis \& Venkatesh, 2000), and the principles of mobile learning by Herrington et al. (2009). Respondents $(\mathrm{n}=13)$ responded a 5 -point Likert scale (from $1=$ "strongly disagree" to $5=$ "strongly agree.). Aside from the questionnaire, the researchers also conducted interviews with three participants. Edwards \& Holland (2013) states that an interview is done in order to study people's understandings toward their recent experience. In this study, the interviews were conducted to the English teacher and the students of the school. The interview of the English teacher was conducted to identify the problem existing in vocabulary learning within the class. The results of the interviews with the students were used to gain a deeper information about students' perception toward the implementation of Quizlet in the classroom.

\section{Data analysis}

Further in this research, the data that had been obtained were analyzed to acquire the answers for the mentioned research questions. The observation was used to analyze students' behavior and the class situation during the implementation of Quizlet. Through the observation, the researchers were able to find the aspect which could still be improved and what problems should be dealt with. In other words, it was helpful for the researchers as a guide to reflect to what had gone right and what aspects needed some improvements during the first and the second cycle. The questionnaire provided quantitative data which were analyzed by finding the mean of each item. By finding the mean, the researchers were able to discover the average score for each item in the questionnaire and able to determine the central tendency for each item and, thus, allowed the researchers to identify which answer or scale in each item has the highest central tendency. The formula used to calculate the data from the questionnaire was mean formula.

The researchers also provided the score responses for each item. The aim was to determine the level of agreement of each item. The researchers used mean distribution formula to determine the range of each scale.

After calculating the score responses of the questionnaire, the result obtained was 0.75 . Hence, ranging from the low up to the very high, the scale range would be as follows: 
Table 1. The scale range of score responses

\begin{tabular}{ccc}
\hline No & Score Range & Interpretation \\
\hline 1 & $1-2$ & Low \\
2 & $2.01-3$ & Moderate \\
3 & $3.01-4$ & High \\
4 & $4.01-5$ & Very high \\
\hline
\end{tabular}

As the researchers has explained in the previous section. The interview was conducted for the teacher in order to identify problems existing within the current practice in English teaching. The result of the interview became the reference for the researchers to make a plan to be implemented in the action phase. As for the interview of the students, the result of the interview was used to gain a deeper information about the students' perception and to support students' responds from the questionnaires. The validity and reliability were ensured by having data source triangulation which was examining evidence from different data sources (observation, questionnaire, and interview). The information gathered was used to build a coherent justification.

\section{FINDINGS AND DISCUSSION}

\section{Quizlet Implementation}

In the first cycle, the researchers used Quizlet as an opening activity. But before the students could access the set, they were required to join the class by typing the class link. After that, they studied the first set of the vocabulary practices. They were given 10 minutes to study the set. They could freely choose between various available features within the application and were not obliged to do repetitions from a particular feature. As Vidal (2003) states in his study that intentional or direct vocabulary learning provided solution for greater words retention. There are various Quizlet features from which the students could choose to study. They are namely Learn, Flashcards, Write, Match, and Test.

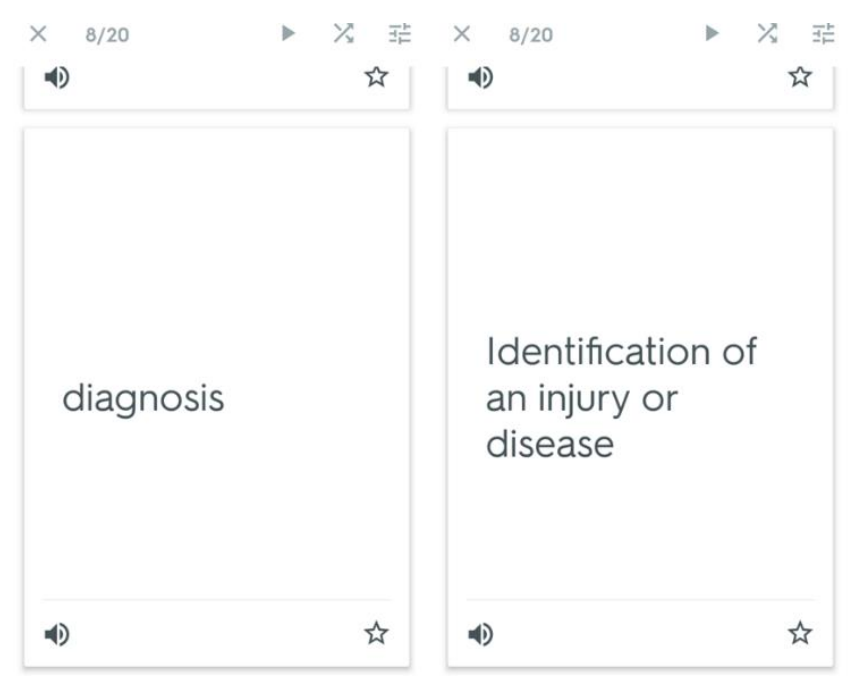

Figure 3. Quizlet's flashcard feature

After studying with Quizlet, the students were given a reading comprehension worksheet. The reading passage contained some of the vocabularies which they had studied from the application. After they read the passage, they answered some questions to test their comprehension. The purpose of this activity was to show the students how the vocabularies they had learned were used in sentences. As Nation (2001) states, learners may need to learn vocabularies in the passage first before reading the passage so that they could better understand the message conveyed. In addition, learners who understand complex vocabulary will be more likely to understand more complex passage and, thus, 
improve their proficiency (Baptist, 2018). Upon finishing the worksheet, the students were not allowed to consult to any dictionary nor Quizlet.

In the second cycle, the students were still provided with two sets of vocabulary lists for two meetings. In this phase, the students studied the set-in middle of the learning activity. Although they could choose freely which features, they want to study from, the researchers suggested the students to try the flashcards feature before they tried the other features. This was done in order to help the students better understand and comprehend each word before they try to test themselves through other features. In the second cycle, the set made for the students contained not only the terms and the definitions of the words, but also a picture of the term and its part of speech.

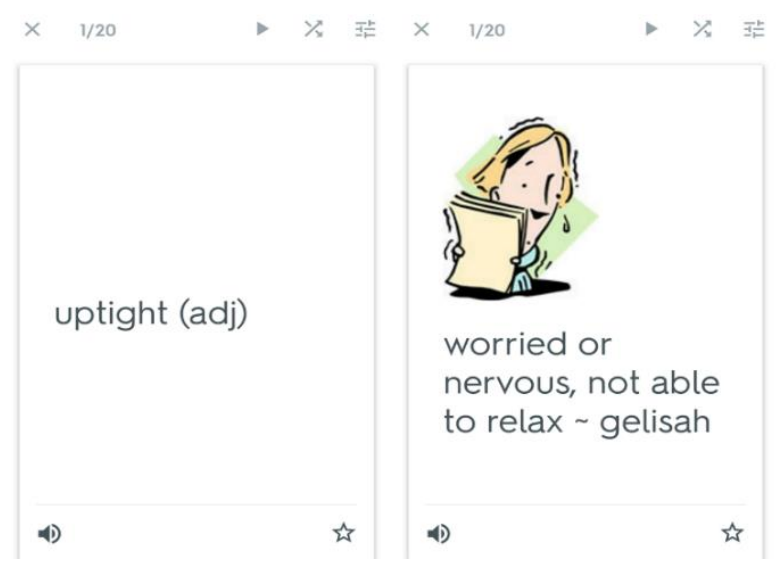

Figure 4. Quizlet's flashcard feature

After studying the set, the students were given a worksheet to test their understanding about the vocabularies they had studied. The worksheet contained vocabularies that they needed to answer after listening to a spoken conversation. After finishing the worksheet, the students played a game which required them to make a sentence from a word they had randomly chosen.

In this phase, the same treatment was given for the students. The sets in this cycle contained some words that were included in the previous two sets so that the students would not need to understand and memorize too many words in each meeting. Moreover, doing repetitions of studying isolated vocabulary is really helpful for learners in order to gain greater retention of the words (de Groot, 2006). Upon finishing studying the set, the students were then given a worksheet containing listening practice, vocabulary practice, and reading comprehension practice. This worksheet contained not only the vocabularies they had learned prior to these activities, it also contained other vocabularies from previous sets.

\section{Students' perception}

The data acquired to answer the second research question were gathered from questionnaires, interviews, and the researchers' observation during the implementation. Although there were 14 students in XI-intermediate class, the researchers only gave the questionnaire to 13 students who were present at least $75 \%$ of the whole implementation process. Besides the questionnaire, the researchers also conducted an interview with 3 students. Davis' theory of Technology Acceptance Model (1989) was divided into two - Perceived Ease of Use (PEU) and Perceived Usefulness (PU). The first part of this section would discuss students' Perceived Ease of Use toward the use of Quizlet in vocabulary learning and students' Perceived Usefulness on the following subtitle.

\section{Perceived Ease of Use}

There were four statements in the questionnaire which discussed Davis' theory of TAM about Perceived Ease of Use. Seeing the results of this variable $(\mathrm{M}=4.38, \mathrm{SD}=0.75)$, it could be concluded that Quizlet was easy to use and the instructions within the application were clear and easy to be understood. Further details will be shown in the table below.

Table 2. Questionnaire result of Perceived Ease of Use 


\begin{tabular}{|c|c|c|c|c|c|}
\hline Question & $\begin{array}{l}\text { Strongly } \\
\text { Disagree }\end{array}$ & Disagree & Agree & $\begin{array}{l}\text { Strongly } \\
\text { Agree }\end{array}$ & Mean \\
\hline -Quizlet is easy to use & $0(0 \%)$ & $0(0 \%)$ & $6(46.15 \%)$ & $7(53.85 \%)$ & 4.54 \\
\hline $\begin{array}{l}\text {-The instructions in Quizlet } \\
\text { are easy to understand }\end{array}$ & $0(0 \%)$ & $1(7.69 \%)$ & $8(61.54 \%)$ & $4(30.77 \%)$ & 4.38 \\
\hline $\begin{array}{l}\text {-I could learn vocabulary } \\
\text { more easily with Quizlet } \\
\text { rather than books }\end{array}$ & $0(0 \%)$ & $2(15.38 \%)$ & $6(46.15 \%)$ & $5(38.46 \%)$ & 4.08 \\
\hline $\begin{array}{l}\text {-I can easily review the } \\
\text { vocabularies I have studied } \\
\text { before in Quizlet }\end{array}$ & $0(0 \%)$ & $0(0 \%)$ & $6(46.15 \%)$ & $7(53.85 \%)$ & 4.54 \\
\hline
\end{tabular}

This result showed that almost all of the students agreed to the first and the second statements of the questionnaire. The result was also supported by one of the students' statement in the interview. The students felt that the application was easy to use and the instructions were simple and easy to understand.

"Once you have joined the class, we could study the sets comfortably. The sets and the content are clear. We could study independently with the features within the app. We could study from the flashcards, the test, and memorize the correct pronunciation easily." (S1/I7).

It could also be seen from the researchers' observation when implementing Quizlet in the classroom. Once the students had been explained of how the features work, they did not ask any more questions nor seemed to be confused in using the application. Furthermore, the students mentioned in the interview that it was more practical to study with Quizlet rather than books.

"Using Quizlet is preferable for me rather than books because it is more practical and more interesting." (S2/I4)

Furthermore, all students agreed that it was easy to review the material they had studied with Quizlet. This item was included in 'very high' within the level of agreement $(\mathrm{M}=4.54, \mathrm{SD}=0.52)$. As Davis (1989) states in his study, an application which is perceived to be easy to use will have a higher chance of getting users' acceptance. This is parallel with the results of the questionnaires, the students' statements in the interview, and the researchers' observation during the implementation of Quizlet which showed their positive attitude toward the application and its easiness to use.

\section{Perceived Usefulness}

The second part of this section would show students' perception about the implementation of Quizlet based on Davis' theory of Perceived Usefulness. There were seven items in the questionnaire which discussed students' perception about Quizlet regarding to its usefulness. Furthermore, interviews with three students were also conducted afterwards. The results of the questionnaire $(\mathrm{M}=4.03, \mathrm{SD}=0.86)$ also indicated that students had favorable views towards Quizlet.

Table 3. Questionnaire result of Perceived Usefulness

\begin{tabular}{lccccc}
\hline \multicolumn{1}{c}{ Statement } & $\begin{array}{c}\text { Strongly } \\
\text { Disagree }\end{array}$ & Disagree & Agree & $\begin{array}{c}\text { Strongly } \\
\text { Agree }\end{array}$ & Mean \\
\hline $\begin{array}{l}\text {-I found Quizlet useful for } \\
\text { my learning }\end{array}$ & $0(0 \%)$ & $0(0 \%)$ & $7(53.85 \%)$ & $6(46.15 \%)$ & 4.46 \\
$\begin{array}{l}\text {-Quizlet has improved my } \\
\text { vocabulary mastery }\end{array}$ & $0(0 \%)$ & $1(7.69 \%)$ & $8(61.54 \%)$ & $4(30.77 \%)$ & 4.15 \\
$\begin{array}{l}\text {-I do not mind spending } \\
\text { my data plan on Quizlet }\end{array}$ & $0(0 \%)$ & $3(23.08 \%)$ & $6(46.15 \%)$ & $4(30.77 \%)$ & 3.85 \\
$\begin{array}{l}\text {-I can learn vocabulary } \\
\text { more effectively with }\end{array}$ & $0(0 \%)$ & $1(7.69 \%)$ & $7(53.85 \%)$ & $5(38.46 \%)$ & 4.23 \\
$\begin{array}{l}\text { Quizlet } \\
\text {-Quizlet provides various } \\
\text { features which make my }\end{array}$ & $0(0 \%)$ & $0(0 \%)$ & $\begin{array}{c}11 \\
(84.62 \%)\end{array}$ & $2(15.38 \%)$ & 4.15
\end{tabular}




\begin{tabular}{|c|c|c|c|c|c|}
\hline $\begin{array}{l}\text {-I can practice my } \\
\text { pronunciation with } \\
\text { Quizlet }\end{array}$ & $0(0 \%)$ & $4(30.77 \%)$ & $7(53.85 \%)$ & $2(15.38 \%)$ & 3.54 \\
\hline $\begin{array}{l}\text {-I could understand the } \\
\text { meaning of a word and } \\
\text { how to use it easier with } \\
\text { Quizlet }\end{array}$ & $0(0 \%)$ & $1(7.69 \%)$ & $9(69.23 \%)$ & $3(23.08 \%)$ & 4.08 \\
\hline $\begin{array}{l}\text {-Quizlet helps me to } \\
\text { prepare for my English } \\
\text { test or quiz }\end{array}$ & $0(0 \%)$ & $0(0 \%)$ & $9(69.23 \%)$ & $4(30.77 \%)$ & 4.31 \\
\hline $\begin{array}{l}\text {-I will use Quizlet for my } \\
\text { further study to help me } \\
\text { improve my vocabulary } \\
\text { mastery }\end{array}$ & $0(0 \%)$ & $4(30.77 \%)$ & $8(61.54 \%)$ & $1(7.69 \%)$ & 3.46 \\
\hline
\end{tabular}

The item which would be discussed first is the statement about whether Quizlet is useful for the students or not. The results showed that all students agreed to these statements, which meant that the students felt that Quizlet was useful in helping them to study vocabulary. The students were also willing to spend their data plan for the application because it was worth it, although there were three students who disagreed with this item. This item had a mean of 3.85 and the standard deviation of this item was 1.14. In the following statement, almost all students (92.3\%) agreed that studying vocabulary with Quizlet was more effective than any other media that they had tried before.

"Although we need to spend our data plan to use the application, because it is an online application, we could learn so much from the app. It has many features and sometimes it has pictures which could help us. Each set also does not contain too many words. We enjoy using the app and it is also a fun app to study with." (S1/I8).

In the next statement, all students agreed that Quizlet provided many features which made their study become interesting. This item had a very high level of agreement with all the students responded to either 'Agree' or 'Strongly Agree' $(\mathrm{M}=4.15, \mathrm{SD}=0.38)$. The next item showed a high level of agreement $(M=4.08, S D=0.76)$. It meant that the students agreed that they could understand the meaning of a word and how to use it easier with Quizlet rather than any other media that they had tried before. This was because the students could practice not only their vocabulary mastery, but also other skill such as pronunciation.

"Aside from learning vocabulary, we could also learn the pronunciation of the words. We could understand the pronunciation right away." (S3/I2)

The next statement in this section which discussed about whether Quizlet helped them to prepare upcoming tests or quiz indicated a very high level of agreement from the students $(\mathrm{M}=4.31$, $\mathrm{SD}=0.48)$. Moreover, the results of the interview also hinted that Mobile Learning, through Quizlet, could open opportunities for the students to do collaborative learning as stated by Herrington et al. (2009).

"In Quizlet, we could try to guess the meaning of the words. It is like playing a game. We could also play (learn) and interact with our friends. Once we feel that we have memorized the words, we could try the Test feature as a practice and to test ourselves." (S1/I3).

The last item discussed whether they will continue using Quizlet for further study in order to improve their vocabulary mastery had a mean of 3.46 with four students stated that they would not use Quizlet for further study. The standard deviation of this item was 1.05. Regarding this, Phua et al. (2012) states in their study that users' PEU and PU do not fully affect users' behavior toward the actual 
and continuous use of any technology although it has positive relation. There are some other factors which would influence users into continuous use of a technology.

\section{Students' perception on the use of Quizlet based on Principles of Mobile Learning}

The table below shows the students' responses from the questionnaire which discussed whether the use of Quizlet fulfilled the principles of Mobile Learning as proposed by Herrington et al. (2009). This variable also had a mean higher than 4 , which showed students' favorable views upon the apps $(\mathrm{M}=$ $4.07, \mathrm{SD}=0.96)$.

Table 4. Questionnaire result of students' perception based on Principles of Mobile Learning

\begin{tabular}{|c|c|c|c|c|c|}
\hline Statement & $\begin{array}{l}\text { Strongly } \\
\text { Disagree }\end{array}$ & Disagree & Agree & $\begin{array}{c}\text { Strongly } \\
\text { Agree }\end{array}$ & Mean \\
\hline $\begin{array}{l}\text {-I can learn vocabulary } \\
\text { anytime and anywhere } \\
\text { with Quizlet }\end{array}$ & $0(0 \%)$ & $0(0 \%)$ & $6(46.15 \%)$ & $7(53.85 \%)$ & 4.54 \\
\hline $\begin{array}{l}\text {-I enjoy using Quizlet to } \\
\text { learn vocabulary }\end{array}$ & $0(0 \%)$ & $1(7.69 \%)$ & $10(76.92 \%)$ & $2(15.38 \%)$ & 4.00 \\
\hline $\begin{array}{l}\text {-After using Quizlet, I } \\
\text { understand that learning } \\
\text { vocabulary can also be } \\
\text { done with the help of } \\
\text { mobile devices }\end{array}$ & $0(0 \%)$ & $1(7.69 \%)$ & $4(30.77 \%)$ & $8(61.54 \%)$ & 4.46 \\
\hline $\begin{array}{l}\text {-I prefer using my mobile } \\
\text { device in learning } \\
\text { vocabulary rather books }\end{array}$ & $0(0 \%)$ & $3(23.08 \%)$ & $6(46.15 \%)$ & $4(30.77 \%)$ & 3.85 \\
\hline $\begin{array}{l}\text {-I become more } \\
\text { autonomous in learning } \\
\text { with my mobile device }\end{array}$ & $0(0 \%)$ & $2(15.38 \%)$ & $7(53.85 \%)$ & $4(30.77 \%)$ & 4.00 \\
\hline $\begin{array}{l}\text {-I gained a new learning } \\
\text { experience after using } \\
\text { Quizlet }\end{array}$ & $0(0 \%)$ & $0(0 \%)$ & $10(76.92 \%)$ & $3(23.08 \%)$ & 4.23 \\
\hline $\begin{array}{l}\text {-I use Quizlet for my } \\
\text { study outside the } \\
\text { classroom }\end{array}$ & $1(7.69 \%)$ & $4(30.77 \%)$ & $5(38.46 \%)$ & $3(23.08 \%)$ & 3.38 \\
\hline
\end{tabular}

From the results above, it could be concluded that the students had favorable opinions toward the use of Quizlet since all of those items in the questionnaire were included in either 'High' or 'Very High' within the scale of level of agreements. The first item in this section, "I can learn anytime and anywhere with Quizlet", had the highest mean among the other items $(\mathrm{M}=4.54, \mathrm{SD}=0.52)$. The result was also emphasized by the student's statement in the interview.

"I sometimes use Quizlet outside the class. Sometimes while I am in the toilet and I get bored, I open the application and do a practice with the Flashcards feature. It is a good way of memorization." (S1/I9).

This result indicates mobile device's ubiquity. The students could study with the application anytime and anywhere. In addition, Herrington et al. (2009) states that Mobile Learning should provide the students with mobile contexts where the students have the mobility in learning. Mobile Learning provides learners with much more flexibility than traditional computing (Ballance, 2012). The next item which discussed whether the students enjoyed using Quizlet had only one students who responded 'Disagree' $(M=4.00, S D=0.71)$. The result is similar to what Baptist (2018) had conducted in her classroom which showed that her students enjoyed using the application for it used various engaging techniques to help the students master vocabulary. Moreover, a student in this research also stated similarly.

"It is fun because I feel like playing game whenever I use the app. I can also do a quiz (Test feature) within the app. I also learn a lot of new vocabularies." (S3/I1) 
In the next statement, "After using Quizlet, I understand that learning vocabulary can also be done with the help of mobile devices", it was proven that almost all students had not been using their mobile devices for studying vocabulary. The statement had a mean of 4.46 and a standard deviation of 0.88 , which could be included in the 'Very High' within the level of agreement range. With Quizlet, they were able to utilize their own mobile devices for studying. Herrington et al. (2009) also stated that Mobile Learning ought to utilize students' own mobile technology. Additionally, most of the students preferred to use Quizlet application to study vocabulary rather than their books $(\mathrm{M}=3.85$, $\mathrm{SD}=1.14)$. There were three students who disagreed with the statement. However, this item still had high level of agreement.

The next statement, "I become more autonomous in learning with my mobile device", had a mean of exactly 4.00 and a standard deviation of 1.00 . There were only two students who felt that their mobile devices, and with the help of Quizlet, did not help them in becoming more autonomous in learning.

"I carry my mobile device every time and and everywhere. I can choose when and where to open the app and start studying. It is way easier and more practical than using books." (S3/I3).

As $\mathrm{Lu}$ (2008) states, the primary advantage that mobile device possesses over traditional methods of learning is its ubiquity. However, Nurhaeni \& Purnawarman (2018) explain that the most common problems faced by students during autonomous studying with their mobile devices are related to technical factors and their internal initiative.

The sixth statement on this section was also included in 'very high' within the level of agreement $(M=4.23, S D=0.44)$. All of the students agreed that Quizlet had given them a new leaning experience with some features that they had never tried before in other learning media. A statement from students also indicated that, before using Quizlet, they only learn vocabulary through handouts, digital dictionary, and online translation machine.

"Before using Quizlet, we were only given handouts filled with lots of words and the meaning. We were a bit unwilling to memorize and learn all the words. Conversely, Quizlet offered us something new that we had never tried before. There are many feature from which we could choose to study." (S1/I8)

The last item on this section discussed whether the students used Quizlet outside the classroom. This item had the lowest mean among all the item in the questionnaire although it was still included in 'High' within the level of agreements with four students responded to 'Disagree' and one student responded to "Strongly Disagree' $(\mathrm{M}=3.38, \mathrm{SD}=1.39)$. Some of them did not use Quizlet outside the class because they thought that the sets only contain the material about the current unit of the English course and it was irrelevant with the other courses. Actually, the users of the application could search millions of other sets who had been made by other creators.

"I have not used Quizlet outside the class because the sets are just about Natural Health. So I can just only study vocabulary related to it and cannot study other materials." (S3/I9).

\section{Discussion}

From the data acquired above, it could be concluded that Quizlet has fulfilled some of the principles proposed by Herrington et al. (2009), although it did not possess all the principle proposed by the researchers such as the principle of 'Real world relevance' because the content of the sets were isolated words. Since vocabulary is one of the most important aspects of a language, it is of vital importance to involve more vocabulary practice in teaching- learning activity. From the data gathered through the questionnaires and interviews, the researchers found three main benefits the students got from the implementation.

The first benefit is that students consider Quizlet as one-stop vocabulary learning application. Quizlet has various features and modes which could really help the students not only to learn the words, but also to test themselves and practice their pronunciation. The Flashcard feature introduce them to the words, they could easily see the words and the definitions just by tapping their screen. The Learn, Write, and Match features help them deepen their understanding toward the words. Lastly, the Test feature could help them to find out how far they have understood what they have learned. 
Moreover, they could also learn the correct utterance of each word. In the interviews, all of the three students mentioned that knowing the correct pronunciation of the words had helped their learning.

Besides being one-stop learning application, students also consider Quizlet as an cutting-edge technology used for learning vocabulary. Studying vocabulary through an application such as Quizlet was something that the students had never experienced before. From the data acquired through the questionnaires and the interviews, it could be seen that the students showed good responses toward the application. All of the questionnaires results indicated either 'High' or 'Very High' level of agreements toward the implementation of the Quizlet, meaning that they experienced the benefits of Quizlet for their learning. This finding strengthen previous studies about learners' perception toward the use of Quizlet (Baptist, 2018; Christanti, 2018; Dizon, 2016)

Students also perceive Quizlet as a practical and easy to use tool. Quizlet can be accessed through computer and mobile devices. This research focused on the implementation of Quizlet through mobile devices. Based on the results of the questionnaires and the interviews regarding to the application's ease of use, the researchers could safely conclude that Quizlet is easy to use. Moreover, two of the three students who did the interviews mentioned that learning through their mobile devices was more practical than learning from books because they did not need to bring a book and write anything. They just needed to take their devices out, open the application, and study the sets right away.

From this implementation, it could be concluded that the problems mentioned in this research has been solved. In the first chapter, the researchers has mentioned that todays' approach of vocabulary learning has been treated as incidental learning and only receives a little attention. From these two cycles of Classroom Action Research, it has been showed that direct vocabulary learning was helpful for the students in learning English. Moreover, the involvement of technology has made the learning become easier and more practical.

\section{CONCLUSION}

After going through two cycles of Quizlet implementation in the classroom, it can be concluded that the students were engaged with this practice. The students could learn independently through their own devices and it was more practical than using books or handouts. Furthermore, the students could practice through different modes which made their learning even more interesting and fun. The data from the questionnaire showed that studying vocabulary with Quizlet was a new experience for all the students. Quizlet could help students learn vocabulary through its interactivity and various modes. All the questionnaire results were included in the 'High' and 'Very High' within the level of agreements, showing students' favorable view toward the implementation of application.

The data acquired from the interviews also showed their favorable view toward this practice. They thought that using Quizlet for vocabulary learning is fun and helpful. One of the students even said that it was like playing a game whenever he used the application and he became more engaged in studying. The students also said that they could study through the application whenever and wherever they want, emphasizing its practicality.

\section{REFERENCES}

Azabdaftari, B., \& Mozaheb, M. A. (2012). Comparing vocabulary learning of EFL learners by using two different strategies: mobile learning vs. flashcards. The EUROCALL Review, 20(2), 47-59.

Ballance, O. J. (2012). Mobile language learning: more than just "the platform." Language Learning and Technology, 16(3), 21-23.

Baptist, S. C. (2018). Effects of Quizlet on vocabulary mastery [Rowan University]. https://rdw.rowan.edu/etd/2555/

Barr, B. (2016). Checking the effectiveness of Quizlet as a tool for vocabulary learning. The Center for English as a Lingua Franca Journal, 2(1), 36-48.

Bukharaev, N., \& Altaher, A. W. (2017). Mobile learning education has become more accessible. American Journal of Computer Science and Information Technology, 5(2), 1-5.

Carr, W., \& Kemmis, S. (1986). Becoming critical: Education, knowledge and action research (1st ed.). Routledge.

Christanti, E. J. (2018). The Use of Quizlet as a Learning Medium to Improve English Vocabulary Mastery for Eleventh Grade in SMAN 4 Yogyakarta. Sanata Dharma University.

Davis, F. D. (1989). Perceived usefulness, perceived ease of use, and user acceptance of information technology. MIS Quarterly: Management Information Systems, 13(3), 319-339. 
https://doi.org/10.2307/249008

Davis, F. D., \& Venkatesh, V. (2000). A theoretical extension of the Technology Accepatance Model: four longitudinal field studies. Management Science, 46(2), 186-204.

de Groot, A. M. B. (2006). Effects of stimulus characteristics and background music on foreign language vocabulary learning and forgetting. Language Learning, 56(3), 463-506.

Dizon, G. (2016). Quizlet in the EFL classroom: enhancing academic vocabulary acquisition of Japanese university students. Teaching English with Technology, 16(2), 40-56.

Edwards, R., \& Holland, J. (2013). What is qualitative interviewing? (1st ed.). London: Bloomsbury.

Herrington, A., Herrington, J., \& Mantei, J. (2009). Design principles for mobile learning. New Technologies, New Pedagogies: Mobile Learning in Higher Education, 129-138. https://doi.org/10.4324/9780203078952-29

Huang, Y.-M., Huang, Y.-M., Huang, S.-H., \& Lin, Y.-T. (2012). A ubiquitous English vocabulary learning system: evidence of active/passive attitudes vs. usefulness/ease-of-use. Computers \& Education, 58(1), 273-282.

Kalecky, R. (2016). Quizlet vs. Vocabulary Notebook: The Impact of Different Methods of Storing and Revising Vocabulary on Students' Progress, Retention and Autonomy. Masaryk University.

Khasinah, S. (2013). Classroom action research. Jurnal Pionir, 1(1), 107-114.

Kukulska-Hulme, A., \& Shield, L. (2008). An overview of mobile assisted language learning: from content delivery to supported collaboration and interaction. ReCALL, 20(3), 271-289. https://doi.org/10.1017/S0958344008000335

Lu, M. M. (2008). Effectiveness of vocabulary learning via mobile phone. Journal of Computer Assisted Learning, 24(6), 515-525.

Moeller, A. J., Ketsman, O., \& Masmaliyeva, L. (2009). The essentials of vocabulary teaching : from theory to practice. Faculty Publications: Department of Teaching, Learning and Teacher Education, 171, $1-16$.

Nation, I. S. P. (1990). Teaching and learning vocabulary. Boston: Heinle \& Heinle Publishers.

Nation, I. S. P. (2001). Learning vocabulary in another language. Cambridge: Cambridge University Press.

Nurhaeni, \& Purnawarman, P. (2018). The use of smartphone and learning strategies in autonomous learning. Indonesian EFL Journal, 4(1), 43-48. https://doi.org/10.25134/ieflj.v4i1.797

Pachler, N., Bachmair, B., \& Cook, J. (2010). Mobile learning: structures, agency, practices. London: Springer.

Paribakht, T. S., \& Wesche, M. (1997). Vocabulary enhancement activities and reading for meaning in second language vocabulary acquisition. Second Language Vocabulary Acquisition: A Rationale for Pedagogy, 55(4), 174-200.

Phua, P. L., Wong, S. L., \& Abu, R. (2012). Factors influencing the behavioural intention to use the internet as a teaching-learning tool in home economics. Procedia - Social and Behavioral Sciences, 59, 180-187. https://doi.org/10.1016/j.sbspro.2012.09.263

Reason, P., \& Bradbury, H. (2008). Handbook of action research: participative inquiry and practice. London: SAGE Publishers.

Ridwan. (2004). Belajar mudah penelitian untuk guru-karyawan dan peneliti pemula. Bandung: Alfabeta.

Surendran, P. (2012). Technology acceptance model: a survey of literature. International Journal of Business and Social Research, 2(4), 175-178.

Taylor, L. (1990). Teaching and learning vocabulary. Hertfordshire: Prentice Hall.

Thornbury, S. (2002). How to teach vocabulary. London: Pearson Education Limited.

Vidal, K. (2003). Academic listening: a source of vocabulary acquisition? Applied Linguistics, 24(1), 5689.

Wallace, M. J. (2010). Action research for language teachers. Cambridge: Cambridge University Press. 